\title{
FREQUENCY OF CCR5 32 MUTATION IN BLOOD DONOR CANDIDATES FROM THE FUNDAÇÃO HOSPITALAR DE HEMATOLOGIA E HEMOTERAPIA DO AMAZONAS, BRAZIL
}

Allyson Guimarães da Costa ${ }^{1,2,3}$, Andréa Monteiro Tarragô ${ }^{1,4}$, Josilene da Silva Abranches $^{1}$, Nadja Pinto Garcia ${ }^{1,4}$, Pedro Vieira da Silva Neto ${ }^{1,4}$, Hiochelson Najibe dos Santos Ibiapina ${ }^{2,3}$, Aya Sadahiro ${ }^{4}$ and Adriana Malheiro ${ }^{1,4}$

\section{ABSTRACT}

The chemokine receptor CCR5 is a major co-receptor for HIV-1 entry into the host cell. Deletion of $32 \mathrm{bp}(\Delta 32)$ alters the receptor structure and is associated with the protection against infection. The distribution of allelic variant depends on several factors influencing the epidemiology of HIV infections. Thus, the present study sought to estimate the allelic frequency of the CCR5 gene variant / CCR5 32 in blood donor candidates with and without positive serology for HIV-1 $1^{+}$at the HEMOAM Foundation. 239 candidates were enrolled and divided into two groups, $\mathrm{HIV}_{-1}{ }^{+}$(101 individuals) and HIV controls (138 individuals). After collecting peripheral blood, DNA was extracted and allele-specific PCR for identification of CCR $5 \Delta 32$ polymorphism, was performed. The results obtained were analyzed using Stata (v.13). The groups were of similar ages, predominantly male and the distribution of genotypes and alleles were in Hardy-Weinberg equilibrium $(\mathrm{p}=0.725$ and $\mathrm{p}=0.879$, respectively). The highest frequency was wild genotype, followed by the heterozygous genotype in both groups (control and the HIV- $-1^{+}$). When the frequencies in $\mathrm{HIV}-1^{+}$subgroups were analyzed,

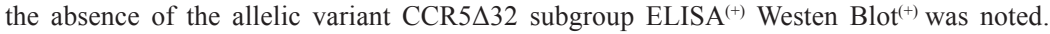
Therefore, our data indicate that CCR $5 \Delta 32$ polymorphism has a low frequency in the population studied.

KEY WORDS: Genetic polymorphism; HIV-1; Amazon.

\footnotetext{
1. Laboratório de Genômica, Fundação Hospitalar de Hematologia e Hemoterapia do Amazonas, Manaus, Amazonas, Brazil. 2. Programa de Pós-Graduação em Medicina Tropical, Universidade do Estado do Amazonas, Manaus, Amazonas, Brazil. 3. Fundação de Medicina Tropical Dr. Heitor Vieira Dourado, Manaus, Amazonas, Brazil

4. Programa de Pós-Graduação em Imunologia Básica e Aplicada, Universidade Federal do Amazonas, Manaus, Amazonas, Brazil.

Corresponding author: Adriana Malheiro, Fundação Hospitalar de Hematologia e Hemoterapia do Amazonas (HEMOAM), Av. Constantino Nery, No 4397, CEP 69050-002, Chapada, Manaus, Amazonas, Brazil. E-mail: malheiroadriana@yahoo.com.br
} 


\section{INTRODUCTION}

Infection by the Human Immunodeficiency Virus (HIV) is characterized by immunosuppression associated with opportunistic infections, malignancies, weight loss, degeneration of the central nervous system (CNS) and may cause Acquired Immune Deficiency Syndrome (AIDS) (Brasil, 2015).

HIV binds to the cell surface through the $\mathrm{CD}^{+}$receptor and the CCR5/ CXCR4 co-receptors to gain entry into cells (Berger et al., 1999). There seems to be a selection of variants of HIV-1 R5 strains, which are responsible for the majority of HIV transmissions while a prevalence of HIV-1 X4 strains is present in some patients with advanced HIV-1 disease. However, HIV-1 and HIV-2 isolates can exploit alternate molecules in vitro as co-factors for viral entry. Several other receptors have been implicated as coreceptors (CCR2b, CCR3, CCR4, CCR6, CCR8, CCR9, CCR10, CXCR2, CXCR5, CXCR6, CX3CR1, XCR1, FPRL1, GPR1, GPR15, APJ, ChemR23, CXCR7/RDC1, D6, BLTR and US28) (Berger et al., 1999; Keele \& Estes, 2011; Santos et al., 2014).

The CCR5 gene encodes a $\mathrm{G}$ protein transmembrane (b-chemokine receptor) and acts as a co-receptor for HIV-1 attachment and entry to T lymphocytes and mononuclear cells through the envelope glycoprotein gp120 binding to the CD4 molecule. Despite high-risk behavior with multiple exposures to HIV-1, some individuals present a rare genetic resistance to HIV1 infection and AIDS related to the CCR5 gene (Liu et al., 1996; Alvarez et al., 1998). The deletion of $32(\triangle 32)$ base pairs in the CCR5 gene leads to the suppression of CC chemokine receptor 5 presentation at the cell surface, thus impeding the HIV entry process into the host cell and protecting against HIV-1 infection (Liu et al., 1996; Samson et al., 1996; Reiche et al., 2007; Février et al., 2011; Vieira et al., 2011; Saez-Cirion et al., 2014; Li, 2015). Besides, three polymorphisms $(-59029,-59353$ and -2459$)$ in the promoter region of CCR5 $(-59029,-59353$ and -2459$)$ have been reported to influence its expression and may modulate the susceptibility of human cells to HIV-1 and Simian Immunodeficiency Virus (SIV) (Zare-Bidaki et al., 2015).

It is noteworthy that the only cure of HIV-1 infection was described in an adult living in Berlin, known as the Berlin patient, who developed acute myelogenous leukemia (AML), was immunosuppressed and treated with an allogeneic hematopoietic stem cell transplant from a donor who was homozygous for the CCR5 $\Delta 32$ deletion (Hütter et al., 2009; Yukl et al., 2013).

The global distribution and ethnic factors for allele CCR5/CCR5 $\Delta 32$ vary significantly, contributing to a variety of genetic resistance profiles to HIV-1 infection seen in different populations (Apostolakis et al., 2005). The variant allele CCR5 32 is relatively common in European populations, whose allele frequency is approximately $10 \%$ (Saez-Cirion et al., 2014), while in Asian populations, allele is absent among the Japanese, Filipino, Korean, 
Chinese and Indians (Martinson et al., 1997). In Brazil, the allelic frequency observed in urban population (198 random unrelated volunteers) was $93 \%$ wildtype homozygous allele (CCR5/CCR5), 7\% in heterozygous allele (CCR5/ CCR5 $\triangle 32$ ) and absence of the variant allele in homozygous (CCR5 $\Delta 32 /$ CCR5 $\triangle 32$ ), resulting in a $3.5 \%$ allele frequency (Passos \& Proença-Picanço, 1998).

Thus, the aim of this study was to estimate the allelic frequency of the CCR5/CCR5 $\triangle 32$ gene variant in candidates for blood donation with and without positive serology for HIV-1 from the Fundacão Hospitalar de Hematologia e Hemoterapia do Amazonas (HEMOAM).

\section{METHODS}

\section{Ethical issues}

The study protocols were approved by the Research Ethics Committee of the Fundacão Hospitalar de Hematologia e Hemoterapia do Amazonas (REC-HEMOAM, process \#0003.0.112.000-11). The free and informed consent form (ICF) was signed by each research subject prior to enrollment, according to the Helsinki Declaration and Resolution 466/12 of the National Health Council for research involving human subjects.

\section{Sampling}

The study samples were obtained from 239 candidates for blood donation at HEMOAM, from April 2006 to March 2007 and August 2012 to July 2013. All the candidates were first-time donors, without previous donation history and were subjected to a detailed serological screening, recommended for the screening of microorganisms transmitted through blood, by the Brazilian Blood Bank Authorities. Blood donor candidates who exhibited HIV reactivity in at least one serological screening test were included in the case group (101 samples), whereas the control group (138 samples), consisted of donors without positive serology for screening markers.

\section{Collection of Samples}

$10 \mathrm{~mL}$ of peripheral blood was collected using the vaccum system in tubes with gel separator (BD gel SST ${ }^{\circledR}$ Advance $^{\circledR}$ II) and PPT (Tube picker K2 EDTA plasma, BD Vacutainer ${ }^{\mathrm{TM}}{ }^{\circledR}$ ) for complete serological testing for $\mathrm{HIV}$ as well as for biomolecular analysis. 
Serological tests were performed by 3rd generation ELISA Axsym I/II g0 ${ }^{\circledR}$ (Abbott, Wiesbaden, Germany) and HIV Ag/Ab combined ${ }^{\circledR}$ (Murex $^{-}$ Biotech, Darford, UK). Confirmatory testing was conducted by Western Blot - Blot 2.2 ${ }^{\circledR}$ (Genelabs Diagnostics, Science Park, Singapore). All the procedures and the results were conducted and evaluated in accordance with the manufacturer's specifications, fulfilling the requirements determined by decree No. 488/98 by the Brazilian Ministry of Health.

\section{DNA extraction}

DNA was extracted with the Brazol kit ${ }^{\circledR}$ (LCG Biotechnology), second protocol developed by Chomczynski and Sacchi (1987), following the recommendations outlined by the manufacturer.

\section{CCR5432 polymorphism genotyping}

Amplification was performed using the PCR technique described by Chies and Hutz (2003). The following pair of primers was used: forward 5'ACCAGATCTCAAAAAGAA3' and reverse: 5'CATGATGGTGAAGATAA-GCTTCA3', derived from previously published sequences in GenBank (AF009962). A total of $25 \mu \mathrm{L}$ of amplification primer mix was used containing $3.0 \mu \mathrm{L}(100 \mathrm{ng})$ of genomic DNA, $1.5 \mu \mathrm{L}(2.5 \mathrm{mM})$ of each primer, $2.0 \mu \mathrm{L}(1.25 \mathrm{mM}) \mathrm{dNTPs}\left(\mathrm{CENT} \mathrm{BIO}{ }^{\circledR}\right), 0.75 \mu \mathrm{L} \mathrm{MgCl}_{2}(50$ $\mathrm{mM}), 2.5 \mu \mathrm{L}$ of 10X PCR buffer (500mM KCl and 200mM Tris-HCl, $\mathrm{pH} 8.4$ ), $2.5 \mu \mathrm{L}(2 \mathrm{U})$ of Taq DNA polymerase $\left(\mathrm{CENT} \mathrm{BIO}^{\circledR}\right)$ and $11.25 \mu \mathrm{L}$ of ultrapure water. PCR was performed in an Applied Biosystems thermocycler (96 Veriti ${ }^{\circledR}$ Thermal Cycler) in accordance with the program described: an initial 1 cycle at $94^{\circ} \mathrm{C}$ for $5 \mathrm{~min}$ (Initial denaturation); 35 cycles: $1 \min \left(94^{\circ} \mathrm{C}\right.$ - denaturation), 1 $\min \left(58^{\circ} \mathrm{C}\right.$ - annealing $)$ and $1 \mathrm{~min}\left(72^{\circ} \mathrm{C}\right.$ - extension $)$; finishing with $10 \mathrm{~min}$ at $72^{\circ} \mathrm{C}$. The fragments generated by PCR (Figure 1 ) were separated by agarose gel electrophoresis at 3\%, stained with GelRed ${ }^{\mathrm{TM}}$ Nucleic Acid Gel Stain $\left(\right.$ Biotium $^{\circledR}$ ) and visualized in ultraviolet transilluminator (UV) light with photo documentation system, Gel+Doc ${ }^{\mathrm{XR}}$ System (Bio-Rad Corporation).

\section{Statistical analysis}

The $\chi^{2}$ two-tailed test and odds ratio (OR) with $95 \%$ confidence interval (CI) were calculated. The Hardy-Weinberg equilibrium (HWE) was estimated, compared to the frequencies of the different genotypes with expected values. Logistic regression analysis was performed using the website https://ihg.gsf. de/cgi-bin/hw/hwa1.pl and STATA software (version 13). 


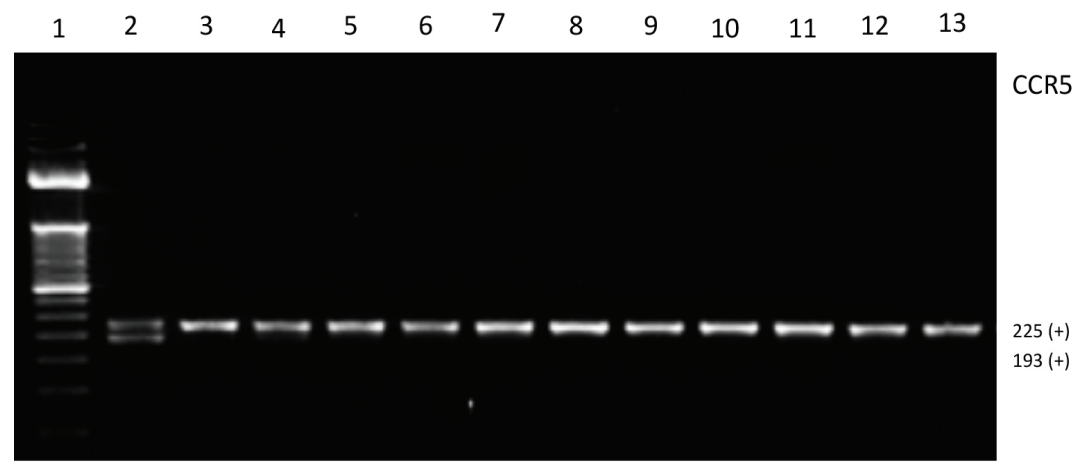

Figure 1. Analysis of Genotype CCR5 in candidates for blood donation at the HEMOAM for Polymerase Chain Reaction (PCR). Agarose gel electrophoresis stained with 3\% GelRed ${ }^{\mathrm{TM}}$ Nucleic Acid Gel Stain. Wild-type allele of the CCR5 gene (225bp) and $32 \mathrm{bp}$ deletion in the gene variant CCR5 32 (193bp). Slots 1: Ladder 50bp. Slots 2: Heterozygous (CCR5/CCR5 432 ). Slots 3-13: Wild Homozygous (CCR5/CCR5).

\section{RESULTS}

Subjects were separated into two groups: control $(\mathrm{n}=138)$ and HIV $-1^{+}$ $(n=101)$. At the confirmatory tests, the HIV-1 ${ }^{+}$group was subdivided into 3

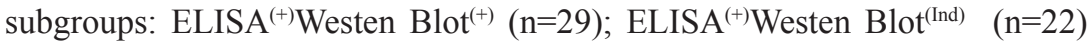
and $\operatorname{ELISA}^{(+)}$Westen blot ${ }^{(-)} \quad(\mathrm{n}=50)$. Demographic data (age and gender) of participants are described in Table 1. The groups had similar age, median of 30 years (controls) and 36 years $\left(\mathrm{HIV}-1^{+}\right)$, with a predominance of males (90 $[65 \%]$ and 79 [78\%], respectively).

The frequency of allelic variants of CCR5 (CCR5/CCR5 $\Delta 32$ ) are shown in Table 2 . The distribution of genotypes and alleles were according to the Hardy-Weinberg expectation $(p=0.725$ and $p=0.879)$. Regarding the allelic frequencies in the control group and HIV-1 ${ }^{+}$, the wild genotype (CCR5/ CCR5) was the most prevalent (94\% and 96\%) followed by the heterozygous genotype (CCR5/CCR5 $\triangle 32$ ) with $6 \%$ and $4 \%$, respectively. The differences were neither statistically significant nor demonstrated association of the allele variant $\mathrm{CCR} 5 \Delta 32$ with $\mathrm{HIV}-1^{+}(\mathrm{OR}=0.497, \mathrm{CI}=0.129$ to $1.924, \mathrm{p}=0.3029)$.

On analysis of the frequencies of $\mathrm{HIV}-1^{+}$subgroups, the absence of the allelic variant CCR5 32 in the subgroup $\mathrm{ELISA}^{(+)}$Westen $\mathrm{Blot}^{(+)}$was noted. The frequencies of this polymorphism in the other subgroups $\left(\mathrm{ELISA}^{(+)}\right.$Westen Blot $^{(\text {Ind) }}$ and ELISA $^{(+)}$Westen Blot $\left.^{(-)}\right)$were lower than in the control group. However, the differences observed were not statistically significant $(\mathrm{p}=0.183$, $\mathrm{p}=0.812$ and $\mathrm{p}=0.627$, respectively), as shown in Table 3 . 
Table 1. Demographic data of candidates for blood donation in the study.

\begin{tabular}{lccccc}
\hline $\begin{array}{l}\text { Demographic } \\
\text { Data }\end{array}$ & $\begin{array}{c}\text { Control } \\
\text { Group }\end{array}$ & & HIV $^{+}$Group & & Total \\
& & $\begin{array}{c}\text { ELISA }^{(+) a} \\
\text { Westen Blot }^{(+) b}\end{array}$ & $\begin{array}{c}\text { ELISA }^{(+)} \\
\text {Westen Blot }^{(\text {Ind.)c }}\end{array}$ & $\begin{array}{c}\text { ELISA }^{(+)} \\
\text {Westen Blot }^{(-) d}\end{array}$ & \\
\hline Number & $(\mathrm{n}=138)$ & $(\mathrm{n}=29)$ & $(\mathrm{n}=22)$ & $(\mathrm{n}=50)$ & $(\mathrm{n}=239)$ \\
Gender (M/F) & $90 / 48$ & $22 / 7$ & $19 / 3$ & $38 / 12$ & $169 / 70$ \\
Age (median) & 30 & 36 & 35 & 36 & \\
\hline
\end{tabular}

${ }^{*}$ M: Male, F: Female. ${ }^{a}$ ELISA $^{(+)}$: Positive ELISA test; ${ }^{b}$ Westen Blot ${ }^{(+)}$: Positive Westen Blot test; ${ }^{\text {CWesten }}$ Blot ${ }^{(\text {Ind): }}$ Indetermined Westen Blot test; ${ }^{\mathrm{d}}$ Westen Blot ${ }^{(-)}$: Negative Westen Blot test.

Table 2. Frequency of genotypes CCR5 $\Delta 32$ according to the study group.

\begin{tabular}{|c|c|c|c|c|c|}
\hline $\begin{array}{l}\text { Genotype / Allele } \\
\text { CCR5 }\end{array}$ & $\begin{array}{l}\text { Control } \\
\text { Group } \\
\text { n }(\%)\end{array}$ & $\begin{array}{l}\mathrm{HIV}^{+} \\
\text {Group } \\
\mathrm{n}(\%)\end{array}$ & $\chi^{2^{*}}$ & $\begin{array}{c}\mathrm{OR}^{\#} \\
\left(95 \% \mathrm{CI}^{\ddagger}\right)\end{array}$ & $\begin{array}{c}(\mathrm{p}) \\
\text { value }\end{array}$ \\
\hline $\mathrm{CCR} 5 / \mathrm{CCR}^{\mathrm{a}}$ & $130(94 \%)$ & $98(96 \%)$ & & & \\
\hline $\mathrm{CCR} 5 / \mathrm{CCR} 5 \Delta 32^{\mathrm{b}}$ & $8(6 \%)$ & $3(4 \%)$ & 1,06 & $\begin{array}{c}0.497(0.129- \\
1.924)\end{array}$ & 0.3029 \\
\hline $\mathrm{CCR} 5 \Delta 32 / \mathrm{CCR} 5 \Delta 32^{\mathrm{c}}$ & 0 & 0 & & & \\
\hline $\begin{array}{l}\text { CCR5 } \\
\text { CCR5 } \triangle 32\end{array}$ & 268 & $\begin{array}{c}199 \\
3\end{array}$ & 1.04 & $\begin{array}{c}0.505(0.132- \\
1.928)\end{array}$ & 0.3699 \\
\hline
\end{tabular}

${ }^{a}$ CCR5/CCR5: Wild-type; ${ }^{b} C C R 5 / C C R 5 \Delta 32$ : Heterozygotes; ${ }^{~} \mathrm{CCR} 5 \Delta 32 / \mathrm{CCR} 5 \Delta 32$ : Homozygotes mutant. ${ }^{*} \chi$ : Chi-square. ${ }^{*} \mathrm{OR}$ : Odds Ratio. ${ }^{*} \mathrm{CI}$ : Confidence Interval 


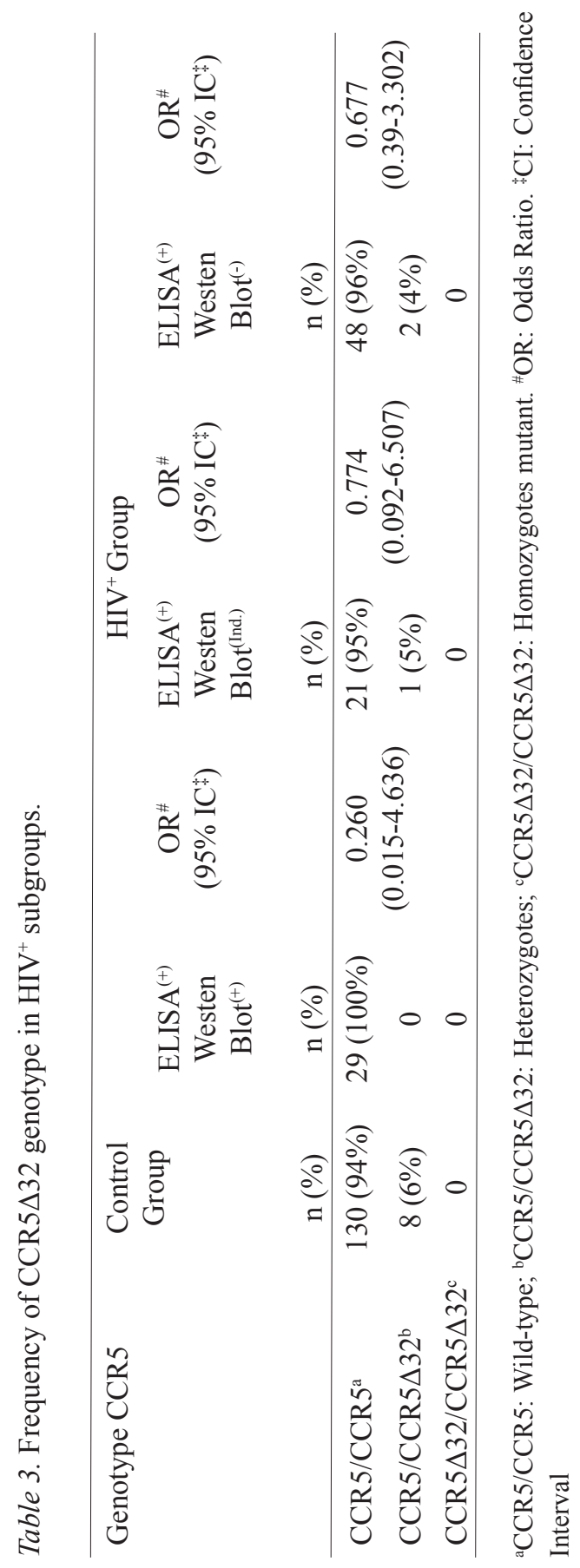




\section{DISCUSSION}

The allelic variant CCR5 $\Delta 32$ has been widely studied in the past decades, due to its association with resistance to HIV-1 infection. Liu et al. (2004) demonstrated that both heterozygous and homozygous CCR5 $\Delta 32$ mutations have a protective effect against HIV-1 infection, since fusion of nucleocapsid viral genetic material with the host cells does not occur. In addition, individuals exhibiting the mutation in homozygous $(\Delta 32 / \Delta 32)$ have been found to be resistant to HIV-1 infection, whereas the presence in heterozygosis slows the progression and involvement of AIDS patients (Sullivan et al., 2001).

In the state of Amazonas, as in the rest of Brazil, HIV infection is associated with sexual transmission in three main groups: men who have sex with men (MSM), sex professionals and intravenous drug users (Oliveira et al., 2015). Men aged 20 to 34 comprise the majority of those infected, being the highest number of AIDS cases (Oliveira et al., 2015). It is known that the presence of the homozygous/heterozygous CCR $5 \Delta 32$ polymorphism may influence HIV infection and modify the epidemiological trends within a population, possibly limiting the spread of HIV-1 and reducing the number of infected individuals (Sullivan et al., 2001).

The frequency of heterozygous polymorphism was $5.7 \%$ in $\mathrm{HIV}-1^{+}$ individuals in São Paulo-SP (Munerato et al., 2003) and 4.4\% in Salvador-BA (Grimaldi et al., 2002). In the states of Rio de Janeiro and Rio Grande do Sul the observed frequencies of heterozygous polymorphisms were $2.1 \%$ and $2.4 \%$ in HIV-infected individuals, data similar to that observed in this study (4\%) (Teixeira et al., 2009; Vieira et al., 2011).

The first Brazilian report of CCR5/CCR5 $\Delta 32$ heterozygotes was provided by Grimaldi et al. (2002), who investigated the occurrence of this allele in different ethnic groups from different regions. They noted a variation in frequency in accordance with ethnicity. The populations described as EuroBrazilian generally had a higher frequency (6.5\% in Joinville-SC and AlegreteRS and $9.3 \%$ in the State of Paraná). In populations described as AfricanBrazilian from the state of Bahia the observed frequency was 5.6\% (Carvalho et al., 2004). The presence of the CCR $5 / C C R 5 \Delta 32$ variant was $0.2 \%$ in Native Americans probably due to mixing with non-Indians, as noted in the Pataxó and Kaingang tribes (Vargas et al., 2006). Similar results to those observed by our group were described by Farias et al. (2012), when they studied 839 individuals in the state of Rondônia, with $2.5 \%$ total frequency observed. In a study conducted in the city of Belém-PA, the frequency of CCR5 $\Delta 32$ seronegative individuals was $2.2 \%$ and $2.7 \%$ in seropositive individuals (Carvalhaes et al., 2005). 
In another study, Leboute et al. (1999), noted the absence of this polymorphism in patients with Amerindian ancestry from the Amazon region, suggesting that the CCR5 $\Delta 32$ variant may be associated with migratory flows occurring in Brazil. In the same study, the authors describe the decreasing allele frequencies from the south $(8.1 \%)$ towards the north $(3.3 \%)$ of Brazil, suggesting the differential influence of European immigration in the various regions.

Although the levels of association observed are similar to other studies performed in populations of the Brazilian Amazon region, this study was limited due to the size of the population studied. Therefore these results should be validated in larger study populations to confirm these findings.

Not with standing, these results contribute to the understanding of the frequency of the CCR5/CCR5 $\Delta 32$ variant allele in candidates for blood donation with and without HIV-1 infection from the city of Manaus-AM. In this study, heterozygous CCR5/CCR5 332 polymorphism was only noted in control subjects and in subjects in the ELISA ${ }^{(+)}$Westen Blot ${ }^{(\text {Ind) }}$ and ELISA ${ }^{(+)}$ Westen Blot ${ }^{(-)}$subgroups. Despite the low frequency of this mutation in this study population, the possibility that this polymorphism may be acting as a natural barrier against HIV infection cannot be excluded. However, again larger study populations need to be investigated in order to enable more accurated inferences on the influence of this polymorphism in this population.

\section{ACKNOWLEDGEMENTS}

We thank the Fundação de Amparo à Pesquisa do Estado do Amazonas (FAPEAM) and the Conselho Nacional de Desenvolvimento Científico e Tecnológico (CNPq) for financial support. We thank Maurício Morishi Ogusku (PhD, INPA), Grenda Leite Pereira (UFAM), and Anamika Dhyani (HEMOAM) for their help in conduction the research.

\section{REFERENCES}

1. Alvarez V, Lopez-Larrea C, Coto E. Mutational analysis of the CCR5 and CXCR4 genes (HIV1 co-receptors) in resistance to HIV-1 infection and AIDS development among intravenous drug users. Hum Genet 102: 483-486, 1998.

2. Apostolakis S, Baritaki S, Krambovitis E, Spandidos DA. Distribution of HIV/AIDS protective SDF1, CCR5 and CCR2 gene variants within Cretan population. J Clin Virol 34: 310-314, 2005.

3. Berger EA, Murphy PM, Farber JM. Chemokine receptors as HIV-1 coreceptors: Roles in viral entry, tropism, and disease. Annu Rev Immunol 17: 657-700, 1999.

4. Brasil. Boletim Epidemilógico HIV/AIDS. Bol Epidemiológico HIVAIDS 2015: 1-100, 2015.

5. Carvalhaes FADPL, Cardoso GL, Vallinoto ACR, Machado LF, Ishak MDOG, Ishak R, Guerreiro JF. Frequencies of CCR5-D32, CCR2-64I and SDF1-3'A mutations in Human Immunodeficiency Virus (HIV) seropositive subjects and seronegative individuals from the state of Pará in Brazilian Amazonia. Genet Mol Biol 28: 665-669, 2005. 
6. Carvalho MWP, Leboute APM, Oliveira SF, Sousa SMB, de Nazaré Klautau-Guimarães M, Simões AL. CCR5D32 mutation in three Brazilian populations of predominantly Sub-Saharan African ancestry. Genet Mol Biol 27: 321-325, 2004.

7. Chies JAB, Hutz MH. High frequency of the CCR5delta32 variant among individuals from an admixed Brazilian population with sickle cell anemia. Brazilian J Med Biol Res 36: 71-75, 2003.

8. Chomczynski P, Sacchi N. Single-step method of RNA isolation by acid guanidinium thiocyanate-phenol-chloroform extraction. Anal Biochem 162: 156-159, 1987.

9. Farias JD, Santos MG, de França AK, Delani D, Tada MS, Casseb AA, Simões AL, Engracia V. Distribution of the CCR5delta32 allele (gene variant CCR5) in Rondônia, Western Amazonian region, Brazil. Genet Mol Biol 35: 27-31, 2012.

10. Février M, Dorgham K, Rebollo A. CD4 +T cell depletion in human immunodeficiency virus (HIV) infection: Role of apoptosis. Viruses 3: 586-612, 2011.

11. Grimaldi R, Shindo N, Acosta AX, Dourado I, Brites C, Melo-Carvalho O, Brito I, Bou-Habib DC, Galvão-Castro B. Prevalence of the CCR $5 \Delta 32$ mutation in Brazilian populations and cell susceptibility to HIV-1 infection. Hum Genet 111: 102-104, 2002.

12. Hütter G, Nowak D, Mossner M, Ganepola S, Müßig A, Allers K, Schneider T, Hofmann J, Kücherer C, Blau O, Blau IW, Hofmann WK, Thiel E. Long-Term Control of HIV by CCR5 Delta32/Delta32 Stem-Cell Transplantation. N Engl J Med 360: 692-698, 2009.

13. Keele BF, Estes JD. Barriers to mucosal transmission of immunodeficiency viruses. Blood 118: 839-846, 2011.

14. Leboute APM, De Carvalho MWP, Simões AL. Absence of the $\Delta \mathrm{ccr} 5$ mutation in indigenous populations of the Brazilian Amazon. Hum Genet 105: 442-443, 1999.

15. Li M. Proteomics in the investigation of HIV-1 interactions with host proteins. Proteomics Clin Appl 9: 221-234, 2015.

16. Liu H, Hwangbo Y, Holte S, Lee J, Wang C, Kaupp N, Zhu H, Celum C, Corey L, McElrath MJ, Zhu T. Analysis of genetic polymorphisms in CCR5, CCR2, stromal cell-derived factor-1, RANTES, and dendritic cell-specific intercellular adhesion molecule-3-grabbing nonintegrin in seronegative individuals repeatedly exposed to HIV-1. J Infect Dis 190: 1055-1058, 2004.

17. Liu R, Paxton WA, Choe S, Ceradini D, Martin SR, Horuk R, MacDonald ME, Stuhlmann H, Koup RA, Landau NR. Homozygous Defect in HIV-1 Coreceptor Accounts for Resistance of Some Multiply-Exposed Individuals to HIV-1 Infection. Cell 86: 367-377, 1996.

18. Martinson JJ, Chapman NH, Rees DC, Liu YT, Clegg JB. Global distribution of the CCR5 gene 32-basepair deletion. Nat Genet 16: 100-103, 1997.

19. Munerato P, Azevedo ML, Sucupira MCA, Pardini R, Pinto GHN, Catroxo M, Souza IE, Diaz RS. Frequency of polymorphisms of genes coding for HIV-1 co-receptors CCR5 and CCR2 in a Brazilian population. Braz J Infect Dis 7: 236-240, 2003.

20. Oliveira RSM, Benzaken AS, Saraceni V, Sabidó M. HIV/AIDS epidemic in the State of Amazonas: characteristics and trends from 2001 to 2012. Rev Soc Bras Med Trop 48: 70-78, 2015.

21. Passos GA, Proença-Picanço V. Frequency of the $\Delta \mathrm{ccr} 5$ deletion allele in the urban Brazilian population. Immunol Lett 61: 205-207, 1998.

22. Reiche EM, Bonametti M, Voltarelli JC, Morimoto HK, Watanabe M. Genetic polymorphisms in the chemokine and chemokine receptors: impact on clinical course and therapy of the human immunodeficiency virus type 1 infection (HIV-1). Curr Med Chem 14: 1325-1334, 2007.

23. Saez-Ciriona JB, Barre-Sinoussi F, Muller-Trutwin M. Immune responses during spontaneous control of HIV and AIDS: what is the hope for a cure? Philos Trans R Soc B Biol Sci 369: 1-17, 2014. 
24. Samson M, Libert F, Doranz BJ, Rucker J, Liesnard C, Farber CM, Saragosti S, Lapoumeroulie C, Cognaux J, Forceille C, Muyldermans G, Verhofstede C, Burtonboy G, Georges M, Imai T, Rana S, Yi Y, Smyth RJ, Collman RG, Doms RW, Vassart G, Parmentier M. Resistance to HIV1 infection in caucasian individuals bearing mutant alleles of the CCR-5 chemokine receptor gene. Nature 382: 722-725, 1996.

25. Santos-Costa Q, Lopes MM, Calado M, Azevedo-Pereira JM. HIV-2 interaction with cell coreceptors: amino acids within the V1/V2 region of viral envelope are determinant for CCR8, CCR5 and CXCR4 usage. Retrovirology 11: 99, 2014.

26. Sullivan AD, Wigginton J, Kirschner D. The coreceptor mutation CCR5 $\triangle 32$ influences the dynamics of HIV epidemics and is selected for by HIV. Proc Natl Acad Sci USA 98: 1021410219, 2001.

27. Teixeira SLM, Bastos FI, Hacker MA, Morgado MG. Distribution of CCR5 genotypes and HLA Class I B alleles in HIV-1 infected and uninfected injecting drug users from Rio de Janeiro, Brazil. Infect Genet Evol 9: 638-642, 2009.

28. Vargas AE, Marrero AR, Salzano FM, Bortolini MC, Chies JAB. Frequency of CCR5delta32 in Brazilian populations. Braz J Med Biol Res 39: 321-325, 2006.

29. Vieira VC, Barral MFM, Mendoza-Sassi RA, Silveira JM, Soares MA, de Martínez AMB. The effect of combined polymorphisms in chemokines and chemokine receptors on the clinical course of HIV-1 infection in a Brazilian population. Mem Inst Oswaldo Cruz 106: 408-414, 2011.

30. Yukl SA, Boritz E, Busch M, Bentsen C, Chun TW, Douek D, Eisele E, Haase A, Ho YC, Hütter G, Justement JS, Keating S, Lee TH, Li P, Murray D, Palmer S, Pilcher C, Pillai S, Price RW, Rothenberger M, Schacker T, Siliciano J, Siliciano R, Sinclair E, Strain M, Wong J, Richman D, Deeks SG. Challenges in Detecting HIV Persistence during Potentially Curative Interventions: A Study of the Berlin Patient. PLoS Pathog 9: e1003347, 2013.

31. Zare-Bidaki M, Karimi-Googheri M, Hassanshahi G, Zainodini N, Kazemi Arababadi M. The frequency of CCR5 promoter polymorphisms and CCR5 $\Delta 32$ mutation in Iranian populations. Iran J Basic Med Sci 18: 312-316, 2015. 